\title{
SPATIAL PLANNING AND THE DEVELOPMENT OF RENEWABLE ENERGY SOURCES IN POLAND
}

\author{
Marta Szyba \\ AGH University of Science and Technology \\ 30 Mickiewicza av., Krakow, 30-059, Poland, mszyba@zarz.agh.edu.pl \\ https://orcid.org/0000-0002-6340-3232
}

Article history: Received 14 January 2021, Received in revised form 23 March 2021, Accepted 29 March 2021, Available online 29 March 2021.

\begin{abstract}
Due to the damage to the environment and climate caused by the generation of electricity in power plants burning fossil fuels, installations generating it from renewable energy sources are constructed. Spatial development plans for communes should consider their location. In Poland, generation of electricity in photovoltaic cells, wind farms and agricultural biogas plants has the greatest development potential. Due to the nuisance to people and the environment, wind turbines and agricultural biogas plants must be located far from residential buildings. Such conditions exist in sparsely populated rural areas. The observed development of single-family housing in rural areas is the result of the search for cheap construction sites and no local spatial development plans in most areas of rural communes. Dispersed housing construction restricts the construction of wind farms and agricultural biogas plants and thus poses a threat to renewable sources of wind and biogas energy produced in agricultural biogas plants. The situation may be changed by the requirement to include in spatial development plans the needs related to the construction of installations generating electricity from renewable energy sources and the construction of micro and small biogas plants directly at the sites where waste is generated.
\end{abstract}

\section{Keywords}

energy management, environmental protection, methane, municipal and agri-food waste, biogas

\section{Introduction}

Until the Industrial Revolution started in Britain in the 18th century, people had drawn their energy to survive and operate from sources that we now call renewable. It was their manual labor, animal labor, wind and water energy. The industrial revolution, symbolized by the steam engine, created a demand for fossil energy resources: coal and lignite, crude oil, natural gas and uranium. Currently, most of the primary energy contained in fossil energy resources is converted into electricity. The result of their combustion is an increase in the content of dust and carbon dioxide in the atmosphere, which is associated with the observed climate changes. The growing demand for energy also causes fears that these raw materials may run out, which threatens the energy security of societies. What is more, their combustion results in an increase in the content of dust and carbon dioxide in the atmosphere. It is associated with the observed climate changes. In order to counteract the threats, technologies are being developed that allow the use of renewable energy sources (RES) for the generation of electricity: wind, water, sun and biogas. The development of renewable energy depends on economic, social, environmental and legal factors [1]. One of the goals of the European Union is to increase the share of RES in gross final energy consumption. For this purpose, "National energy and climate plans for 2021-2030" must be created and their effects will be assessed by the European Commission. The Polish plan assumes that in 2030 this share will amount to at least 23\% (electricity, heat and cooling) [2]. This direction will be continued after 2030, as evidenced by the resolution of the Council of Ministers on "Poland's energy policy until 2040" [3].

Generating electricity from RES requires space for the installations themselves and the associated protection zones. The need for creating protection zones results from the negative impact on people and the environment (e.g., odors from agricultural biogas plants, infrasound generated by wind turbines). It is impossible for people to live in the zones, as agricultural production and other economic activities are hindered. Reconciling the demand for space for RES installations with the needs for other user groups is the task of spatial planning at the national, regional and municipal levels. Without providing places for such installations, it will not be possible for Poland to achieve the goal of an emission-free economy adopted by the European Union.

This article will present the effects of the functioning of the existing laws: on spatial planning and spatial development and on the protection of agricultural and forest land. The current effects of implementing renewable energy programs will also be discussed and an attempt will be made to explain them using the agrarian structure of farms and demographic conditions in individual voivodships. 
The aim of this article is to indicate the factors that favor the location of wind farms and agricultural biogas plants. Recognizing them and taking them into account at the planning stage will help us avoid protests from local communities. This will enable efficient investment processes of new installations and prevent conflicts during their operation.

\section{Methods}

The following research methods were used: review and analysis of legal acts and scientific literature; analysis of data published by the Central Statistical Office, analysis of data obtained from the Energy Regulatory Office and National Support Center for Agriculture. Effects of the binding act on spatial planning and spatial development for housing investments are presented and related to the use of renewable energy. The current effects of using such sources as wind turbines and agricultural biogas plants are discussed. The current effects of implementing RES utilization programs were discussed and explained using the agrarian structure of farms and demographic conditions in individual voivodships.

\section{Results and discussion}

\section{Spatial planning in Poland}

Spatial development plans constitute the legal basis and an instrument of spatial policy within the territory of the country, shaping the activities of the society at various levels of integration [4]. In Poland, it is carried out based on the Act on Spatial Planning and Development of March 27, 2003 and subsequent amendments [5]. Taking sustainable development as the basis for shaping spatial order, the Act recommends that spatial planning should consider several requirements listed in Art. 1, point 2. They concern urban planning and architecture, architectural and landscape values (including monuments and cultural heritage), environmental protection (including agricultural land, forest land and water), health and safety of people and property, and the future needs related to the development of infrastructure technical and renewable energy use. Spatial planning should be open and transparent with the participation of local society and with respect for property rights.

The Act distinguishes three levels of planning: national, regional (provincial) and communal. Planning at the communal level has the greatest impact on RES-related investments due to the participation and control of the local community.

It includes the development of:

- a study of the conditions and directions of spatial development (SUiKZP),

- a local spatial development plan (MPZP) [5].

Developing UiKZP studies for communes is obligatory. They must include conditions resulting from: the current destination, land development and utilities, environment, cultural heritage, communication system, water and sewage management, energy, living conditions of residents, safety, legal status of land and facilities, mineral deposits and the implementation of supra-local public goals. In turn, the directions should define the following: changes in the spatial structure of the commune and land use, development of communication systems and technical infrastructure, planned areas for the distribution of settlement zones and large-scale commercial facilities, areas for which local development plans are to be prepared, areas of special threats, boundaries of protection zones, etc. The directions should also include provisions on the location of devices generating energy from renewable sources with a power above $100 \mathrm{~kW}$ and their protection zones [5]

According to the research conducted by the Institute of Geography and Spatial Organization of the Polish Academy of Sciences [6], at the end of 2017, only 5 local governments (3 rural communes and 2 urban-rural communes) had no such document, and another 4 studies were in the process of being developed. The documents can be easily changed. In 2017, 1/3 of the documents were updated nationwide, and almost a half for cities with powiat (county) status. In the studies, approximately $11 \%$ of communes' areas were allowed for development and additionally $8 \%$ for farm buildings (related to running agricultural farms). According to the authors of the report, this is too much, although less than the 14.2\% allowed for this purpose in 2010.

The study of the conditions and directions of spatial development is not a legal act. The local spatial development plan (Local Development Plan) is such an act. It is binding on local government bodies that issue construction permits. The permits are issued by construction departments on behalf of the land and town starosts. The local spatial development plan is a planning study implementing the spatial policy adopted in the UiKZP study of the commune. It contains provisions on the purpose and rules for the development of specific areas of the commune [5]. The situation with local development plans is not good, it results from the previously mentioned studies. At the end of 2017, there were 51.6 thousand local plans, covering 9.6 million ha or $30.5 \%$ of the country's area. As compared to 2004, it was an increase of 13.2 percentage points and there are no indications that most of the 
country's area will be covered in the coming years. Only a few major cities and their suburban zones have local plans for more than half of their areas. The worst situation is recorded in the following voivodships: KujawskoPomorskie, Podkarpackie and Lubuskie. Local plans there cover less than $10 \%$ of the area. In the local development plans, $1,188,000$ ha is intended for housing and farm buildings, which constitutes $20.5 \%$ of the areas covered by them ( $5.9 \%$ of the country's area). According to the authors of the report, it is too much and contributes to the excessive dispersion of buildings [6].

In areas that are not covered by the Local Plan, construction permits are issued based on decisions on construction conditions and land development (WZiZT). Such decisions are issued by local government bodies (wójt, mayors, city mayors). Such a decision can be obtained with the title to the plot on which the construction is to take place. Since the study of the conditions and directions of spatial development is not a legal act, a building permit can be obtained even if the area is intended for other purposes (e.g., agricultural, public purposes, flood protection, RES energy production). Using the provisions of the Act on the Protection of Agricultural and Forest Land of February 3, 1995, it is quite easy to obtain changing the status of land from agricultural land and designate it for development [7]. A decision on WZiZT is in principle issued for an indefinite period, as it may only be repealed by the adoption of MPZP. If the plot is impaired as a result of that, the owner may apply for compensation. Low coverage of the country with local plans results in many decisions on development conditions. In the years 2003-2017, over 2 million of them were issued, including about 5\% of refusals. In 2017, there were 22.7 thousand decisions to determine the location of a public purpose and 32.5 thousand zoning ones, of which $65 \%$ for individual single-family housing [6]. This results in an overflow of buildings, being the reason for high costs related to the development of infrastructure, especially the road network [8].

The data presented in [6] shows that the current planning situation is not good, due to insufficient coverage of the country's territory with local spatial development plans. It is particularly dangerous for the sustainable development of the Polish countryside defined in 2010 in the document of the Ministry of Agriculture and Rural Development [9].

\section{Structure of agricultural farms}

Most of the communes in Poland are rural 1,533 (62.7\%) and 642 urban-rural (25.9\%). According to the Statistical Yearbook of the Central Statistical Office of 2019, on December 31,2018,15,344,000 people lived in the countryside (39.95\%) of Polish citizens. Most of the 1,428.8 thousand farms that conducted their activity on 14,669 thousand ha of agricultural land, which constitute $46.99 \%$ of the country's area, operated in the countryside. Utilized agricultural area (UAA) includes arable land, permanent pastures and meadows, orchards, built-up agricultural land, wooded and bushy land on agricultural area, land under breeding ponds [10]. The UAA is one of the basic parameters of an agricultural farm. The methodology of research on the typology of farms described in [11] enables studying the dynamics of changes in the agrarian structure of voivodships. Based on it, voivodships were grouped in terms of their similarity. Table 1 shows the structure of farms in individual voivodships s in 2008 and 2016. The division into groups of voivodships presented in Table 1 results from [1113] presenting the results of research on the typology of farms in individual voivodships.

The data in Table 1 shows that in 2008-2016, the number of farms across the country decreased by 395.8 thousand (21.91\%). This caused changes in the agrarian structure of individual voivodships. Group I, including three voivodships, is characterized by the most fragmented structure. There are approx. $80 \%$ farms with an area of 1-5 ha. In group II, also including three voivodships, the smallest farms constitute about half of all farms, and farms with an area of 5-10 ha are 25-30\%. In this group, the percentage of the largest farms was slowly increasing. Group III includes six voivodships, where the number of the smallest farms decreased to the level below $40 \%$ and increased in the remaining ranges. In 2016, the largest farms were in the Warmińsko-Mazurskie voivodship, and $12.2 \%$ in the Zachodniopomorskie voivodship. In group IV there was over $10 \%$ reduction in farms with an area of 1-5 ha and there was over 3\% increase in the largest farms. In Lubuskie voivodship they constituted $8.2 \%$. The agrarian structure of the Świętokrzyskie Province is not included in any of the groups.

Part of the land of liquidated farms did not increase other farms, but was allocated for non-agricultural purposes, such as: communication and commercial and service infrastructure, industrial and housing construction. The knowledge of the structure of farms and the changes taking place in it is important not only for the agricultural policy but for the entire spatial planning, especially housing and the use of renewable energy sources. 
Table 1. Changes in the agrarian structure of voivodships in 2008-2016. Source: own study based on [11-13]

\begin{tabular}{|c|c|c|c|c|c|c|c|c|}
\hline \multirow{2}{*}{ Group } & \multirow{2}{*}{ Voivodeship } & \multirow{2}{*}{ Years } & \multirow{2}{*}{$\begin{array}{l}\text { Number of } \\
\text { farms in } \\
\text { thousands }\end{array}$} & \multicolumn{5}{|c|}{ Percentage of farms with UAA in ha } \\
\hline & & & & $1-5$ & $5-10$ & $10-20$ & $20-50$ & $>50$ \\
\hline \multirow{6}{*}{$\mathbf{I}$} & Małopolskie & 2008 & no data & 84.6 & 12.6 & 2.2 & 0.5 & 0.1 \\
\hline & & 2016 & 139.9 & 82.4 & 13.1 & 3.1 & 1.0 & 0.4 \\
\hline & Śląskie & 2008 & no data & 78.7 & 13.3 & 5.5 & 1.9 & 0.6 \\
\hline & & 2016 & 54.5 & 71.5 & 15.9 & 7.4 & 3.7 & 1.6 \\
\hline & Podkarpackie & 2008 & no data & 82.2 & 14.5 & 2.2 & 0.9 & 0.2 \\
\hline & & 2016 & 13.9 & 82.4 & 12.4 & 3.0 & 1.5 & 0.7 \\
\hline \multirow{6}{*}{ II } & Łódzkie & 2008 & no data & 49.7 & 30.8 & 15.3 & 3.7 & 0.4 \\
\hline & & 2016 & 124.0 & 51.1 & 27.9 & 15.0 & 5.3 & 0.8 \\
\hline & Mazowieckie & 2008 & no data & 48.3 & 29.4 & 16.6 & 5.1 & 0.5 \\
\hline & & 2016 & 212.9 & 45.6 & 27.9 & 18.0 & 7.2 & 1.3 \\
\hline & Lubelskie & 2008 & no data & 56.3 & 27.2 & 12.3 & 3.6 & 0.5 \\
\hline & & 2016 & 180.0 & 55.5 & 25.3 & 12.7 & 5.2 & 1.3 \\
\hline \multirow{12}{*}{ III } & Podlaskie & 2008 & no data & 30.6 & 26.3 & 29.3 & 12.6 & 1.1 \\
\hline & & 2016 & 82.2 & 28.1 & 26.8 & 27.6 & 14.9 & 2.7 \\
\hline & Wielkopolskie & 2008 & no data & 39.6 & 25.5 & 22.9 & 9.6 & 2.3 \\
\hline & & 2016 & 12.2 & 40.4 & 23.6 & 21.8 & 10.8 & 3.5 \\
\hline & Kujawsko-pomorskie & 2008 & no data & 34.6 & 24.6 & 23.6 & 14.8 & 2.5 \\
\hline & & 2016 & 63.8 & 33.7 & 22.3 & 24.2 & 15.4 & 4.5 \\
\hline & Pomorskie & 2008 & no data & 39.0 & 23.1 & 22.6 & 11.8 & 3.6 \\
\hline & & 2016 & 39.0 & 34.8 & 23.4 & 22.6 & 13.2 & 6.0 \\
\hline & Warmińsko-mazurskie & 2008 & no data & 33.5 & 15.5 & 27.5 & 17.7 & 5.8 \\
\hline & & 2016 & 43.2 & 29.7 & 17.3 & 23.3 & 20.7 & 9.0 \\
\hline & Zachodniopomorskie & 2008 & no data & 44.4 & 19.0 & 16.1 & 11.4 & 9.1 \\
\hline & & 2016 & 29.6 & 37.1 & 19.3 & 18.8 & 12.6 & 12.2 \\
\hline \multirow{8}{*}{ IV } & Lubuskie & 2008 & no data & 58.8 & 19.5 & 11.3 & 6.6 & 3.8 \\
\hline & & 2016 & 20.2 & 48.2 & 18.2 & 15.4 & 10.0 & 8.2 \\
\hline & Dolnośląskie & 2008 & no data & 55.1 & 21.7 & 13.7 & 6.7 & 2.9 \\
\hline & & 2016 & 56.0 & 44.3 & 21.9 & 14.3 & 8.7 & 5.9 \\
\hline & Opolskie & 2008 & no data & 57.2 & 18.6 & 12.6 & 8.7 & 2.9 \\
\hline & & 2016 & 26.9 & 45.4 & 18.2 & 17.3 & 12.7 & 6.3 \\
\hline & Świętokrzyskie & 2008 & no data & 68.1 & 24.3 & 6.0 & 1.5 & 0.2 \\
\hline & & 2016 & 85.3 & 65.1 & 22.6 & 9.0 & 2.7 & 0.5 \\
\hline \multirow{2}{*}{\multicolumn{2}{|c|}{ Poland }} & 2008 & 1806.5 & 57.1 & 22.8 & 13.4 & 5.4 & 1.3 \\
\hline & & 2016 & 1410.7 & 53.8 & 22.0 & 14.5 & 7.2 & 2.5 \\
\hline
\end{tabular}

\section{Housing construction after 1990}

According to the data presented in [6] too many locations related to housing construction are determined based on WZiZT. This is the result of efforts aimed at improving the housing situation of Poles, resulting from losses in both world wars and the housing policy in the planned economy system in Poland until 1990. According to the Central Statistical Office (GUS) data, in 1989 there were 10.9 million apartments with an average usable floor space of $60.5 \mathrm{~m}^{2}$. According to the same source, in 1988 there were 10.71 million flats per 11.97 million households. The shortage was therefore about 1.25 million flats. Cities were dominated by multi-family housing; investors were mostly housing cooperatives. They constructed on land provided free of charge by the state for preferential loans. The waiting time for an apartment was exceptionally long and the size of the apartment allocated depended on the size of the family.

In the new socio-economic system, housing construction began to be financed by future users from their own resources and mortgage loans. As a result of the changes, in 2017 there were already 14.4 million apartments with an average area of $74.0 \mathrm{~m}^{2}$, which places Poland in the sixth place from the end among $28 \mathrm{EU}$ countries [14]. As the average floor space of a flat in the EU is $96.0 \mathrm{~m}^{2}$, it should be expected that the demand for land for housing development will still be high. Developers will continue to look for such sites in rural areas. Due to the 
widespread automotive industry and the availability of the Internet, areas within $50 \mathrm{~km}$ from large cities may be attractive for single-family housing. This will result in declining urbanization rates and increasing rural population density [9]. This will have a negative impact on the possibility of using wind energy and agricultural biogas to produce electricity.

Table 2. Changes in population density and urbanization indicators in voivodships in 2009-2019. Source: Own study based on [10]

\begin{tabular}{|c|c|c|c|c|c|c|}
\hline \multirow{2}{*}{ Group } & \multirow{2}{*}{ Vivodeship } & \multicolumn{2}{|c|}{$\begin{array}{l}\text { Population density people / } \\
\qquad \mathrm{km}^{2}\end{array}$} & \multicolumn{3}{|c|}{ Urbanization rate $\%$} \\
\hline & & Total & Rural areas & 2009 & 2019 & $2019-2009$ \\
\hline \multirow[t]{3}{*}{$I$} & Małopolskie & $225^{*}$ & 131 & 49.26 & 48.20 & -1.06 \\
\hline & Śląskie & $366 *$ & 124 & 78.10 & 76.60 & -1.50 \\
\hline & Podkarpackie & 119 & 75 & 41.06 & 41.40 & 0.34 \\
\hline \multirow[t]{3}{*}{ II } & Łódzkie & $135 *$ & 54 & 64.16 & 52.37 & -11.79 \\
\hline & Mazowieckie & $153^{*}$ & 58 & 64.62 & 64.46 & -0.16 \\
\hline & Lubelskie & 84 & 47 & 46.53 & 46.45 & -0.08 \\
\hline \multirow[t]{6}{*}{ III } & Podlaskie & 58 & 24 & 60.16 & 60.64 & 0.48 \\
\hline & Wielkopolskie & 117 & 57 & 56.12 & 54.00 & -2.12 \\
\hline & Kujawsko-pomorskie & 115 & 50 & 60.73 & 58.89 & -1.84 \\
\hline & Pomorskie & $128 *$ & 50 & 66.21 & 63.49 & -2.72 \\
\hline & Warmińsko-mazurskie & 59 & 25 & 59.86 & 59.19 & -0.67 \\
\hline & Zachodniopomorskie & 74 & 25 & 68.66 & 68.43 & -0.23 \\
\hline \multirow[t]{4}{*}{ IV } & Lubuskie & 72 & 27 & 63.61 & 64.90 & 1.29 \\
\hline & Dolnośląskie & $145^{*}$ & 52 & 70.27 & 68.41 & 1.29 \\
\hline & Opolskie & 104 & 54 & 52.32 & 53.24 & 0.92 \\
\hline & Świętokrzyskie & 105 & 62 & 45.17 & 45.39 & 0.22 \\
\hline & Poland & 123 & 53 & 60.98 & 60.01 & -0.97 \\
\hline
\end{tabular}

*above the average for Poland

The data in Table 2 shows that in 2009-2019, the urbanization rate in Poland decreased by 0.97\%. A decrease in the urbanization rate was recorded in the following voivodships: Małopolskie, Śląskie, Łódzkie, Mazowieckie, Lubelskie, Wielkopolskie, Kujawsko-Pomorskie, Pomorskie, Warmińsko-Mazurskie, Zachodniopomorskie. The largest decreases were recorded in the following voivodeships: Łódzkie (by $11.79 \%$ ), Pomorskie (by 2.72\%), Kujawsko-Pomorskie (by $1.84 \%$ ) and Śląskie (by $1.5 \%$ ).

Migration of the urban population to rural areas already causes conflicts with farmers. They are associated with field work and animal husbandry. In order to counteract protests trying to limit agricultural activity in rural areas, there was a demand from the National Council of Agricultural Chambers that new residents, when applying for a construction permit, sign a statement that they know about the specificity of agricultural activity and the related difficulties that do not occur in cities (machinery work at night, animal sounds, smells from breeding) [15].

\section{Wind farms and agro-gas plants as proposed RES systems}

In Poland, it is possible to increase the generation of electricity from solar, wind and agricultural biogas [16]. Solar energy is converted into electricity by photovoltaic cells. They can be mounted on roofs of buildings of any purpose in cities and villages. Solar farms can also be established in degraded post-industrial areas and wastelands. The use of wind energy and biogas for the generation of electricity is, in principle, only possible in rural areas. They have an appropriate spatial and demographic structure enabling the construction of wind farms. In the case of agricultural biogas plants, they also have the substrates needed for methane fermentation. Currently, the largest amount of electricity from renewable energy sources in Poland is being generated by wind turbines. They are almost exclusively three-blade devices with a horizontal axis of rotation, with towers over 100 
$\mathrm{m}$ high and the power of generating sets over $100 \mathrm{~kW}(0.1 \mathrm{MW})$ [16]. Power plants are most often connected to the power grid in groups and treated as one installation.

According to data from the Energy Regulatory Office, on October 15, 2020, there were 1,207 wind installations in Poland with a total capacity of 5,917.243 MW (see table 3).

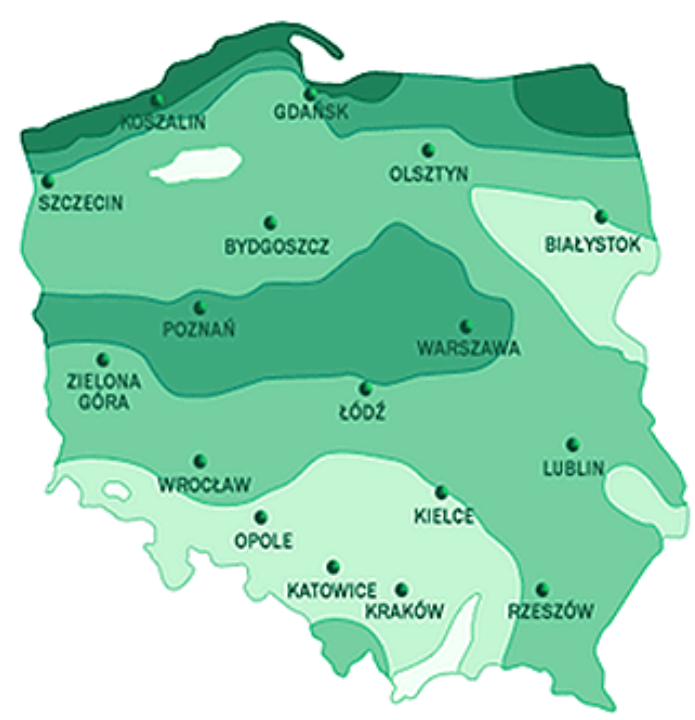

Legend:

Fig. 1. Wind energy zones in Poland.

Source: [17]

Figure 1 shows the division of Poland into energy wind zones. The conditions of the seaside, being several kilometers long, and in the north-east of the Warmińsko-mazurskie Voivodeship are extremely favorable. They are favorable up to several dozen kilometers from the Baltic Sea and near the border with the Russian Federation and in the center of the country. This zone stretches from the western part of the Mazowieckie Voivodeship, through parts of the Kujawsko-pomorskie Voivodeship and Wielkopolskie Voivodeship, to the northern part of the Lubuskie Voivodeship. Extremely unfavorable conditions prevail in the southern part of the Dolnośląskie Voivodeship, in the following voivodships: Opolskie, Śląskie, Małopolskie, Świętokrzyskie and partly Podlaskie and Lubelskie. Appropriate wind conditions are not a sufficient condition for the location of wind installations. Appropriate distances from: buildings, protected areas, forests, lakes, etc. must also be kept. It is also important that there are MPZP adopted and approved by the commune authorities and the local community. [16].

Table 3 presents the number of installations in individual voivodships, their total capacity and the average capacity per installation. The data included therein shows that there are few installations in the $1^{\text {st }}$ group of voivodships and the individual wind farms belonging to them have low capacity. It is associated with unfavorable wind conditions, but also with the high population density of rural areas and the fragmentation of agricultural farms. The influence of the recent factors may be proved by a small number of wind installations and their low capacity. In the Małopolskie Voivodeship, where there are more than $80 \%$ of the smallest farms and the population density in rural areas exceeds 76 people $/ \mathrm{km}^{2}$, there are only 11 installations with an average capacity of $0.539 \mathrm{MW}$. The largest installations are there in the 3rd group of voivodships with better wind conditions, lower population density in rural areas and a higher percentage of large agricultural farms. The best situation is in the Zachodniopomorskie Voivodeship, where there is the highest installed capacity, and the average installation capacity is $55.115 \mathrm{MW}$. In this voivodship, in 2016, one fourth of farms had more than 20 ha of UAA (including $12 \%$ over 50 ha of UAA), the population density in rural areas was below 45 people $/ \mathrm{km}^{2}$. In Poland wind turbines have limited development opportunities due to the wind conditions and need to be constructed far away from human settlements. The act of 20 May 2016 on investments in wind farms introduced a regulation that they can be located at a distance not less than 10 times the height of the object [19]. In the case of the already existing ones, it reduces the possibility of reconstruction in order to increase their power, as this is most often associated with increasing their height. A significant increase in electricity generation from wind will be possible after the construction of planned wind farms in the offshore coastal zone. 
Table 3. Number of wind installations and their parameters in voivodships. Source: Compilation based on [18]

\begin{tabular}{|c|c|c|c|c|}
\hline Group & Voivodeship & $\begin{array}{l}\text { Number of } \\
\text { installations }\end{array}$ & $\begin{array}{l}\text { Total power } \\
\text { in MW }\end{array}$ & $\begin{array}{l}\text { Power per } \\
\text { installation }\end{array}$ \\
\hline \multirow{3}{*}{$\mathbf{I}$} & Małopolskie & 11 & 5.932 & 0.539 \\
\hline & Śląskie & 29 & 34.195 & 1.266 \\
\hline & Podkarpackie & 25 & 152.956 & 5.665 \\
\hline \multirow{3}{*}{ II } & Łódzkie & 208 & 580.969 & 21.517 \\
\hline & Mazowieckie & 98 & 385.301 & 14.270 \\
\hline & Lubelskie & 12 & 138.900 & 5.144 \\
\hline \multirow{6}{*}{ III } & Podlaskie & 29 & 197.760 & 7.324 \\
\hline & Wielkopolskie & 231 & 726.210 & 26.897 \\
\hline & Kujawsko-pomorskie & 302 & 606.035 & 22.446 \\
\hline & Pomorskie & 61 & 711.615 & 26.356 \\
\hline & Warmińsko-mazurskie & 44 & 356.985 & 13.222 \\
\hline & Zachodniopomorskie & 98 & 1488.095 & 55.115 \\
\hline \multirow{4}{*}{ IV } & Lubuskie & 15 & 193.080 & 6.532 \\
\hline & Dolnośląskie & 12 & 176.36 & 6.532 \\
\hline & Opolskie & 12 & 140.900 & 5.219 \\
\hline & Świętokrzyskie & 20 & 21.950 & 0.813 \\
\hline & Poland & 1207 & 5917.243 & 4.902 \\
\hline
\end{tabular}

The second group of power plants the operation of which is related to agricultural areas are agricultural biogas plants. They use biogas for generation: animal manure, wastes from agricultural production, processing of fruit and vegetables as well as corn and grass silage. The biogas they produce contains $40-85 \%$ methane [20]. The potential of Polish agriculture and the agri-food industry allows for the production of about 5 billion $\mathrm{m}^{3} /$ year of agricultural biogas with the parameters of high-methane natural gas [20]. The biogas produced is most often burned in cogeneration units generating electricity and heat. The former is fully transferred to the power grid. Thermal energy is partly (about 30\%) used to heat the substrates in the methane fermentation process and to heat the biogas plant premises. It can also be sold to external recipients if the distance from them allows it. According to the ERO data (included in Table 4 dated October 15, 2020, there were 105 agricultural biogas plants in Poland with a total capacity of 112,158 MW [21].

The number of agricultural biogas plants running is very small in relation to the assumptions adopted in 2010 the Council of Ministers document "Trends in development of agricultural biogas plants in Poland 2010-2020" [the program]. The document states that by 2020 there will be an average of one biogas plant in each municipality. As there are 1,523 rural communes and 652 urban-rural communes in Poland, the program failed [22]. As in the case of wind farms, most agricultural biogas plants operate in voivodships belonging to group III, with the highest percentage of large agricultural farms and low population density in rural areas. In the voivodships, the average installed capacity ranges from 0.975 to $1.351 \mathrm{MW}$. The smallest (one in each) biogas plants are in the Opolskie (2.00 MW) and Świętokrzyskie (0.800 MW) voivodships. There is also a small number of biogas plants in the following voivodships: Małopolskie (2), Śląskie (2) and Podkarpackie (3), i.e., those with the most fragmented agrarian structure.

The register of biogas producers kept by KOWR shows that on June 2, 2020, on December 29, 2020,116 cogeneration units with a total capacity of $117.804 \mathrm{MW}$ were installed in Polish AgroGas plants. The most numerous group (45) were aggregates with a capacity of 0.751-1.00 MW (see Table 5.). There were $81.9 \%$ of aggregates with a capacity of more than $0.501 \mathrm{MW}$. High-power agricultural biogas plants require large acreage for the cultivation of plants suitable for biogas production (maize, grain, grass) or very large farms of cattle, pigs and poultry, which increases transport costs and causes the emission of odors that are nuisance for the inhabitants [23]. 
Table 4. Number of agricultural biogas plants and their parameters in voivodships. Source: study based on [23]

\begin{tabular}{|c|l|c|c|c|}
\hline Group & \multicolumn{1}{|c|}{ Voivodeship } & $\begin{array}{c}\text { Number of } \\
\text { installations }\end{array}$ & $\begin{array}{c}\text { Total power } \\
\text { in MW }\end{array}$ & $\begin{array}{c}\text { Power per } \\
\text { installation }\end{array}$ \\
\hline \multirow{3}{*}{ I } & Małopolskie & 2 & 1.148 & 0.574 \\
\cline { 2 - 5 } & Śląskie & 2 & 1.596 & 0.798 \\
\cline { 2 - 5 } & Podkarpackie & 3 & 2.498 & 0.833 \\
\hline \multirow{3}{*}{ II } & tódzkie & 4 & 5.057 & 1.264 \\
\cline { 2 - 5 } & Mazowieckie & 7 & 7.898 & 1.128 \\
\cline { 2 - 5 } & Lubelskie & 8 & 10.858 & 1.357 \\
\hline \multirow{3}{*}{ III } & Podlaskie & 9 & 7.675 & 0.853 \\
\cline { 2 - 5 } & Wielkopolskie & 12 & 12.661 & 1.055 \\
\cline { 2 - 5 } & Kujawsko-pomorskie & 8 & 10.211 & 1.276 \\
\cline { 2 - 5 } & Pomorskie & 9 & 12.159 & 1.351 \\
\cline { 2 - 5 } & Warmińsko-mazurskie & 12 & 11.705 & 0.975 \\
\cline { 2 - 5 } & Zachodniopomorskie & 13 & 12.690 & 0.976 \\
\hline \multirow{3}{*}{ IV } & Lubuskie & 4 & 2.792 & 0.698 \\
\cline { 2 - 5 } & Dolnośląskie & 10 & 10.410 & 1.041 \\
\cline { 2 - 5 } & Opolskie & 1 & 2.000 & 2.000 \\
\hline \multirow{2}{*}{} & Świętokrzyskie & 1 & 0.800 & 0.800 \\
\hline \multirow{2}{*}{} & Poland & 105 & 112.158 & 1.068 \\
\hline
\end{tabular}

Table 5. Size structure of cogeneration units. Source: study based on [23]

\begin{tabular}{|c|c|}
\hline Aggregate power in MW & Number of aggregates \\
\hline$<0,100$ & 3 \\
\hline $0.101-0.250$ & 3 \\
\hline $0.251-0.500$ & 15 \\
\hline $0.501-0.750$ & 10 \\
\hline $0.751-1.000$ & 45 \\
\hline $1.001-1.500$ & 16 \\
\hline $1.501-2.000$ & 18 \\
\hline $2.001-2.500$ & 6 \\
\hline Total & 116 \\
\hline
\end{tabular}

However, the low population density is not the only factor that must be considered when choosing the location of agricultural biogas plants. A very important factor is the acceptance of the construction by the inhabitants. Its lack is due to the odors associated with such substrates as slurry and other animal excrements, which are particularly nuisance during transport from farms to biogas plants. An example of the lack of acceptance may be the commune of Tuczno, where the population density is only 20.1 people $/ \mathrm{km}^{2}$. In the village of Rzeczyca, which belongs to this commune, there is a biogas plant with a capacity of 3.985 million $\mathrm{m}^{3}$ of biogas/year and an installed electrical capacity of $0.999 \mathrm{MW}$. The idea of building a second biogas plant in the commune led to a referendum in which the commune head was dismissed [24]. Table 5 shows that only 3 biogas plants had a power lower than $0.100 \mathrm{MW}$ and 3 had a power of 0.101-0.250 MW. Meanwhile, many EU countries are building large numbers of smaller biogas plants located next to livestock farms using their own substrates. The animal excrements are directly injected from the manure tanks into the digesters. This prevents the spread of odors outside the farm. And so, in Switzerland, where the population density is over 200 people $/ \mathrm{km}^{2}$, in 2013 there were 100 biogas plants with an average capacity of $0.207 \mathrm{MW}$. In the Zurich region, the capacity of biogas plants was even lower ( 8 with an average capacity of $0.115 \mathrm{MW}$ ) [25]. On the other hand, in Austria, the average capacity of 243 biogas plants was $0.297 \mathrm{MW}$. 


\section{Impact}

Achieving the goal of a climate neutral economy by 2050 is an excessively big challenge for Poland. Currently, it has $70 \%$ of energy based on hard coal and lignite. The fossil energy resources must be replaced by renewable energy sources. In Poland, photovoltaic installations, wind farms and big agricultural biogas plants will be the most important producers of clean electricity.

Due to the impact on people and the environment, wind farms and agricultural biogas plants may be in sparsely populated areas. In Poland, they are rural areas with large agricultural farms (over 50 ha of UAA). Moreover, such farms and the related agri-food industry provide the substrates needed to produce biogas. The number of such farms is growing due to the liquidation of smaller farms. At the same time, in rural areas there is an increase in single-family housing construction. It results from the housing deficit inherited from the command and distribution system, lower prices of construction sites than in cities and the no local spatial development plans for most areas of rural communes. In the absence of such, construction and land development conditions which result in dispersed residential buildings are issued. Such constructions block the possibility of locating wind farms and agricultural biogas plants. As a result, this can lead to Poland not being able to achieve the goal of an emission-free economy. Limiting the possibility of such development requires changes in the provisions on spatial planning and protection of agricultural and forest land.

\section{Conclusions}

Such renewable energy sources as wind farms and agricultural biogas plants are located in sparsely populated rural areas due to the nuisance and threats to the inhabitants. Large areas belonging to one owner also allow the construction of wind farms (wind farms) with the necessary access roads and a network of connections. There are also few residential buildings in such areas, and it is possible to keep a minimum distance from them, even with windmills over 100 meters high. Large acreages of farms foster monocultures of crops intended for fodder (e.g., maize) but also that can be used for the production of silage for biogas. On such farms, large livestock farms (poultry, cattle, pigs) are built. They breed animals that produce large amounts of waste (slurry, manure, bird droppings) that are harmful to the environment but can be used for the production of biogas. The best solution would be to introduce a requirement to locate biogas plants using manure on the area of such farms. These would be mostly micro and small biogas plants with a capacity of up to $0.1 \mathrm{MW}$, but there could be a lot of them, as there were only dairy cows herds with more than 150 heads at the end of 2018459 [26]. The construction of such biogas plants will reduce the amount of greenhouse gas emitted, which is methane extracted from the excrements of animals stored outside.

The housing deficit and high land prices in cities, locating housing (especially single-family houses) in rural areas, may threaten plans to transition to an environmentally safe, emission-free economy. Eventually, it is necessary to accelerate the creation of local spatial development plans, especially in rural communes. When developing these plans, the needs of energy based on renewable energy sources should be considered. In addition, amendments to the Act on the Protection of Agricultural and Forest Land are needed, which now make it too easy to de-agriculture.

\section{Conflict of interest}

There are no conflicts to declare.

\section{Acknowledgments}

The study was carried out as part of a research project financed by the statutory grant of the AGH University of Science and Technology in Krakow for the maintenance of research potential.

\section{References}

[1] K. Olczak, Odnawialne żródła energii jako przesłanka prawna bezpieczeństwa energetycznego, Stud. Prawno-Ekonomiczne. 117 (2020) 115-128. https://doi.org/10.26485/spe/2020/117/7.

[2] Krajowy Plan na Rzecz Energii i Klimatu na lata 2021-2030, Ministerstwo Klimatu i Środowiska, Warsaw, 2019. https://www.gov.pl/web/klimat/krajowy-plan-na-rzecz-energii-i-klimatu.

[3] Polityka Energetyczna Polski do 2040 r., Ministerstwo Klimatu i Środowiska, Warsaw, 2021.

[4] T. Kurowska, Planowanie przestrzenne a zrównoważony rozwój obszarów wiejskich, Stud. lurid. Agrar. 14 (2016) 47-61. https://doi.org/10.15290/sia.2016.14.03.

[5] Ustawa z dnia 27 marca 2003 r. o planowaniu i zagospodarowaniu przestrzennym, Dz.U. 2003 Nr 80 Poz. 717. (2003).

[6] Analiza stanu i uwarunkowań prac planistycznych w gminach w 2017 roku, Instytut Geografii 
i Przestrzennego Zagospodarowania PAN, Warszawa, 2018. http://eregion.wzp.pl/sites/default/files/prace_planistyczne_w_gminach.pdf.

[7] Ustawa z dnia 3 lutego 1995 r. o ochronie gruntów rolnych i leśnych, Dz.U. z 2017 r. Poz. 1161, z 2020 r. Poz. 471. (2005) 1-9.

[8] M. Feltynowski, Planowanie przestrzenne na obszarach wiejskich łódzkiego obszaru metropolitalnego a problem rozprzestrzeniania się miast (Spatial planning of rural areas of łódź metropolitan area and the problem of urban sprawl), Infrastrukt. i Ekol. Teren. Wiej. 13 (2010) 111-121.

[9] Kierunki rozwoju obszarów wiejskich założenia do "strategii zrównoważonego rozwoju wsi i rolnictwa," Ministerstwo Rolnictwa i Rozwoju Wsi, Warsaw, 2010. http://www.lir.lublin.pl/download/projekty/dok_kons_288.pdf.

[10] Rocznik Statystyczny Rzeczypospolitej Polskiej, Główny Urząd Statystyczny, 2019.

[11] J. Bożek, B. Bożek, Typologia struktury agrarnej województw w ujęciu dynamicznym z zastosowaniem klasyfikacji rozmytej., Metod. Ilościowe w Badaniach Ekon. XII (2011) 91-100.

[12] J. Bożek, D. Bogocz, Przestrzenne zróżnicowanie struktury agrarnej województw w ujęciu dynamicznym, Zesz. Nauk. Małopolskiej Wyższej Szk. Ekon. w Tarnowie. $20 \quad$ (2012) 21-37. https://doi.org/10.25944/znmwse.2012.01.2138.

[13] J. Bożek, J. Szewczyk, Zmiany struktury obszarowej gospodarstw rolnych w ujęciu grup typologicznych województw, Wiadomości Stat. 64 (2019) 19-31. https://doi.org/10.5604/01.3001.0013.7597.

[14] A. Dobkowska, Powierzchnia mieszkaniowa w Polsce poniżej średniej w UE, 2018. https://www.locja.pl/raport-rynkowy/powierzchnia-mieszkania-w-polsce-ponizej-sredniej-w-ue,110.

[15] https://agri24.pl/chcesz-zamieszkac-wsi-zloz-oswiadczenie-ze-bedziesz-mial-zadnych-roszczen/, (2018).

[16] B. Soliński, Zarządzanie hybrydowymi systemami wytwarzania energii elektrycznej wykorzystującymi odnawialne źródła energii., AGH, Kraków, 2015.

[17] http://www.builddesk.pl/edukacja/zrodla-energi/energia-wiatrowa, (2021).

[18] Letter DSK-056-84(4)/2020/IRŚ., (2020).

[19] Ustawa z dnia 20 maja 2016 r. o inwestycjach w zakresie elektrowni wiatrowych, (2016).

[20] W. Podkówka, Biogaz rolniczy odnawialne źródło energii. Teoria i praktyczne zastosowanie, Powszechne Wydawnictwo Rolnicze i Leśne, Warszawa, 2012.

[21] A. Piwowar, M. Dzikuć, Charakterystyka podmiotów zajmujących się wytwarzaniem biogazu rolniczego w Polsce, J. Agrobus. Rural Dev. 1 (2013) 207-217.

[22] Kierunki rozwoju biogazowni rolniczych w Polsce w latach 2010-2020, Ministerstwo Gospodarki, Warszawa, 2010. https://www.teraz-srodowisko.pl/media/pdf/aktualnosci/1043-kierunki-rozwojubiogazowni-rolniczych.pdf.

[23] https://www.kowr.gov.pl/odnawialne-zrodla-energii/biogaz-rolniczy/wytworcy-biogazu-rolniczego, (2017).

[24] https://waszemedia.pl/?p=40925, (2020).

[25] B. Stürmer, D. Leiers, V. Anspach, E. Brügging, D. Scharfy, T. Wissel, Agricultural biogas production: A regional comparison of technical parameters, Renevable Energy. 164 (2021) 171-182. https://doi.org/10.1016/j.renene.2020.09.074.

[26] https://pfhb.pl/fileadmin/user_upload/OCENA/publikacje/publikacje_2019/3_0_Wyniki_2018_tabele, (2019). 